\title{
INVENTARISASI DAN DESKRIPSI PENYAKIT DAUN PADA TANAMAN TEMBESU (Fagraea fragrans) DI SUMATERA BAGIAN SELATAN
}

\author{
Inventory and Description of Leaves Disease on Tembesu (Fagraea fragrans) Plantation \\ in Southern Sumatra
}

\author{
Asmaliyah $^{1)}$, Illa Anggraeni ${ }^{2)}$ dan/and Hengki Siahaan ${ }^{3)}$ \\ ${ }^{1,3)}$ Balai Penelitian Kehutanan Palembang \\ ${ }^{2)}$ Pusat Penelitian dan Pengembangan Bogor \\ Kampus Balitbangsi, J1. Gunung Batu No. 5 Kotak Pos 165 Bogor 16118, Jawa Barat, Indonesia \\ Telp. 0251-8633234; Fax. 0251-8638111 \\ Email: asmaliyah-bp2ht@yahoo.com ${ }^{1)}$
}

Tanggal diterima: 6 Januari 2014; Tanggal direvisi: 30 Juli 2015; Tanggal disetujui: 11 Agustus 2015

\begin{abstract}
Disease is a serious problem in development of forest plantation as it the plant. Effective and efficient control should be supported by information about its pathogen and ecobiology. The research aimed to inventorize the leaf diseases and the impact of its attacks on tembesu in Southern Sumatera. The study used purposive sampling method. The results showed: 1) Five pathogens were founded namely yellow spot disease caused by Diplodia mutila, yellowish green spot disease caused by Curvularia sp., brownish-yellow spot disease caused by Pestalotiopsis sp., the brown spot disease caused by Phyllosticta capitalensis and black mildew disease caused by Meliola sp.; 2) The attack intensity was categorized as rather heavy; 3) yellow spot disease caused by D. mutila was the most widely spreading in Southern Sumatera with attack intensity of 20,36\%; 4) black mildew disease caused by Meliola sp. had limited spreading but the highest attack intensity is $22,98 \%$ and 5) could be applied plant spacing agroforestry to control leafdisease.
\end{abstract}

Keywords: Tembesu, leaf spot disease, black mildew disease

\begin{abstract}
ABSTRAK
Serangn penyakit merupakan permasalahan serius dalam pembangunan hutan tanaman karena yang dapat menyebabkan kematian tanaman. Pengendalian penyakit yang efektif dan efisien haurs didukung informasi mengenai penyebab penyakit dan ekobiologinya. Penelitian ini bertujuan untuk menginventarisasi penyakit daun dan dampak serangannya terhadap tanaman tembesu di Provinsi Sumatera Selatan, Jambi dan Lampung. Metode penelitian menggunakan purposive sampling. Hasil penelitian menunjukkan bahwa: 1) ada 5 jenis penyakit dan patogen pada tegakan tembesu, yaitu penyakit bercak kuning disebabkan cendawan Diplodia mutila; penyakit bercak hijau kekuningan disebabkan cendawan Curvularia sp., penyakit bercak kuning kecokelatan disebabkan oleh cendawan Pestalotiopsis sp., dan penyakit bercak cokelat disebabkan cendawan Phyllosticta capitalensis serta penyakit embun hitam disebabkan cendawan Meliola sp.; 2) intensitas serangan penyakit tersebut termasuk kategori serangan agak berat; 3 ) penyakit bercak daun $D$. mutila merupakan penyakit yang paling luas sebarannya pada tegakan tembesu di Sumatera Bagian Selatan dengan intensitas serangan 20,36\%;4) penyakit embun hitam Meliola $s$. merupakan penyakit paling terbatas keberadaannya, namun memiliki intensitas serangan paling tinggi, yaitu $22,98 \%$; dan 5) mengendalian serangan penyakit daun dapat diupayakan dengan penggunaan jarak tanam lebar dan perlu penerapan pola tanam agroforestri.
\end{abstract}

Kata kunci: Tembesu, penyakit bercak daun, penyakit embun hitam

\section{PENDAHULUAN}

Pembangunan hutan tanaman merupakan $\mathrm{u}-$ paya untuk memenuhi kebutuhan bahan baku kayu. Kebutuhan kayu pertukangan semakin meningkat, khususnya untuk jenis komersil lokal.
Jenis komersil lokal yang sedang dikembangkan saat ini di Sumatera Selatan adalah tembesu (Fagraea fragrans Roxb.). Upaya pengembangan hutan tanaman tembesu sangat bergantung pada keberhasilan dalam mengatasi masalahmasalah yang dihadapi seperti ketidaksesuaian 
jenis tanaman dengan tapak, serangan hama dan penyaki serta perkembangan pasar kayu. Untuk mendapatkan hutan tanaman tembesu yang berkualitas baik harus menguasai cara perlindungan tanaman dari serangan pengganggu, khususnya serangan penyakit. Hal ini dikarena-kan dengan terjadinya perubahan kondisi hutan yang heterogen menjadi hutan yang homogen telah menimbulkan masalah peningkatan serangan penyakit.

Serangan penyakit merupakan salah satu faktor yang dapat menghambat keberhasilan pembangunan hutan tanaman. Dalam beberapa kasus serangan penyakit pada tanaman dapat mengakibatkan terjadinya penurunan kualitas kayu, terhambatnya pertumbuhan tanaman (Anggraeni \& Wibowo, 2007) bahkan kematian tanaman (Rahayu, 2008). Seperti misalnya, serangan penyakit busuk akar (root rot) pada tanaman Acacia mangium yang disebabkan oleh patogen Ganoderma spp. dan Rigidoporus lignosus dapat menghambat pertumbuhan (Old et al., 2000) bahkan dapat menimbulkan kematian tanaman (Widyastuti et al., 2005). Serangan penyakit daun berupa karat puru pada tanaman sengon yang disebabkan oleh cendawan Uromycladium tepperianum dapat menyebabkan kematian tanaman sengon muda dan penurunan kualitas kayu pada sengon yang siap dipanen (Rahayu et al., 2010; Triyogo \& Widyastuti, 2011; Anggraeni, 2012). Serangan lanjut penyakit bercak daun pada tanaman Gmelina arborea dapat menyebabkan kematian tanaman karena proses fotosintesis tidak terjadi, akibatnya aktivitas sel terhenti (Anggraeni \& Mindawati, 2011).

Serangan penyakit daun pada komoditas per- tanian dan perkebunan bahkan dapat menyebabkan penurunan produksi atau kehilangan hasil yang cukup nyata. Hasil penelitian Umrah et al. (2009), menunjukkan bahwa serangan penyakit daun pada tanaman kakao yang disebabkan oleh cendawan Phytopthora palmivora dapat menyebabkan kerugian sebesar 32-50\% dan bahkan pada daerah yang mendukung perkembangan patogen tersebut akan lebih besar lagi kerugiannya. Nurhayati et al. (2010), mengemukakan bahwa tanaman karet kolon GT 1 yang terserang penyakit gugur daun Corynespora cassicola selama 2 bulan dapat menurunkan produksi getah diatas 40\% dari produksi normal. Di Amerika Selatan, serangan penyakit daun pada tanaman karet yang disebabkan oleh cendawan Microcylus ulei dapat menyebabkan pertumbuhan pohon lambat, produksi karet rendah dan bisa menyebabkan kematian apabila penggundulan daun terjadi dalam beberapa musim (Guyot, 2014). Oleh karena itu upaya perlindungan tanaman dari serangan penyakit perlu diketahui.

Berdasarkan hal tersebut maka kegiatan penelitian berupa inventarisasi dan deskripsi penyakit pada tanaman tembesu sangat diperlukan, karena sampai saat ini hasil penelitian atau informasi mengenai jenis penyakit pada tanaman tembesu masih relatif sangat terbatas. Diketahuinya jenis penyakit dan patogen penyebab penyakit serta ekobiologinya, maka tindakan pencegahan/pengendalian dapat ditentukan. Tujuan penelitian adalah menginventarisasi penyakit daun dan dampak serangannya terhadap tanaman tembesu di Provinsi Sumatera Selatan, Jambi dan Lampung.

Tabel(Table) 1. Lokasi penelitian inventarisasi penyakit pada tanaman tembesu di Sumatera Bagian Selatan (Research location of inventory of disease on tembesu in Southern Sumatera)

\begin{tabular}{llll}
\hline No. & Propinsi (Province) & Kabupaten & Kecamatan \\
\hline \multirow{2}{*}{} & Sumatera Selatan & Ogan Ilir (OI) & - Sungai Pinang \\
& & Ogan Komering Ilir (OKI) & - Kayu Agung \\
& & - Pedamaran Timur \\
\cline { 2 - 3 } & Muara Enim & - Gelumbang \\
& & - Talang Ubi \\
\cline { 2 - 3 } & Ogan Komering Ulu Timur & - Muara Enim \\
\hline & (OKUT) & - Semendawai Barat \\
\cline { 2 - 3 } & & Banyuasin & - Tungkal Ilir \\
& & - Pangkalan Balai \\
& & - Banyuasin III \\
\hline 2 & Jambi & Musi Banyuasin & - Sekayu \\
\hline & & Sarolangun & - Lais \\
\hline 3 & Lampung & Batang Hari & - Pelawan Singkut \\
\cline { 2 - 3 } & Muaro Bungo & - Pasar Muaro Bungo \\
\hline
\end{tabular}

Sumber (Source): Asmaliyah (2010) 


\section{METODOLOGI}

\section{A. Lokasi dan Waktu Penelitian}

Penelitian dilakukan pada areal tegakan tembesu yang ada di Propinsi Sumatera Selatan, Jambi dan Lampung, baik berupa tegakan alami maupun tegakan hasil penanaman. Lokasi-lokasi tersebut secara lengkap dapat dilihat pada Tabel 1. Penelitian dilakukan mulai bulan Maret 2010 sampai dengan Desember 2011.

\section{B. Bahan dan Peralatan}

Bahan yang digunakan dalam penelitian ini antara lain tegakan tembesu, alkohol, aquadest, aluminium foil, plastik wrap, kertas koran, tally sheet, dan lain-lain. Alat yang digunakan adalah hand counter, kotak plastik, ice box, kuas, spidol permanen, kantong plastik, gunting, kamera, cawan petri, lampu bunsen, jarum ose, ruang isolasi $(\mathrm{LAF}=$ Laminar Air Flow $)$, media agar-kentang (PDA $=$ Potatoes Dextrose Agar), otoklaf, oven dan lain-lain.

\section{Metode Penelitian}

\section{Inventarisasi dan Deskripsi penyakit}

Kegiatan bertujuan untuk mengetahui jenis penyakit yang menyerang tanaman tembesu di lapangan. Kegiatan inventarisasi dilakukan pada kebun milik petani yang terserang penyakit di desa yang dijadikan sebagai lokasi pengamatan. Luasan areal setiap lokasi pengamatan bervariasi, sehingga luasan untuk sampel pengamatan juga bervariasi. Luasan areal untuk sampel pengamatan diambil $20 \%$ dari luasan areal yang ada, yang dijadikan sebagai petak pengamatan. Petak pengamatan tersebut kemudian dibagi dalam plot-plot kecil sebanyak 5 buah, kecuali di Desa Sidomulya, Kecamatan Tungkal Ilir, Kabupaten Banyuasin, jumlah plot hanya 3 buah. Ukuran plot bervariasi dengan jumlah tanaman pada setiap plot pengamatan sebanyak 30-50 tanaman pada pola tanam monokultur, sedangkan pada pola tanam campuran atau agroforestry jumlah tanaman berkisar antara 15-20 tanaman. Penetapan plot-plot ditentukan dengan metode systemic sampling. Sebaran plot pengamatan ditempatkan pada pojok lokasi dan tengah lokasi. Pengamatan dan pengumpulan data dilakukan pada plot pengamatan secara sensus dengan mengamati seluruh tanaman tembesu yang ada dalam setiap petak pengamatan. Parameter yang diamati adalah gejala serangan dan patogen penyebabnya. Daun yang sakit sebagai sumber patogen yang diduga menjadi penyebab penyakitnya diperlukan untuk mengetahui patogen penyebabnya.

\section{Pengamatan dan Pengukuran Persentase Serangan dan Intensitas Serangan}

Pengamatan dan pengumpulan data persentase serangan dan intensitas serangan dilakukan secara sensus terhadap semua tanaman yang ada. Persentase serangan $(\mathrm{P})$ diperoleh dengan menggunakan rumus:

$\mathrm{P}=\frac{\text { Jumlah tanaman yang terserang dalam suatu petak ukur }}{\text { Jumlah seluruh tanaman dalam suatu petak ukur }} \times 100 \%$

Adapun intensitas serangan secara kuantitatif didapat dengan menggunakan rumus Direktorat Perlindungan Tanaman (2000), yaitu:

$$
\mathrm{I}=\frac{\Sigma(\mathrm{ni} \mathrm{x} \mathrm{vj})}{\mathrm{ZXN}} \times 100 \%
$$

Keterangan (Remarks):

I : Intensitas serangan

ni : Jumlah pohon yang terserang dengan klasifikasi tertentu

vj : Nilai untuk klasifikasi tertentu

$\mathrm{Z}$ : Nilai tertinggi dalam klasifikasi

$\mathrm{N}$ : Jumlah pohon seluruhnya dalam suatu plot

Intensitas serangan secara kualitatif dapat diklasifikasikan menurut pedoman Sugiharso \& Suseno (1983), yang di modifikasi (Tabel 2).

Tabel (Table) 2. Klasifikasi tingkat kerusakan daun yang disebabkan oleh penyakit (Classification level of leaf damage was caused by pests)

\begin{tabular}{llc}
\hline $\begin{array}{c}\text { Tingkat Kerusakan } \\
\text { (Level of damage })\end{array}$ & $\begin{array}{c}\text { Tanda kerusakan yang terlihat pada tanaman } \\
\text { (Signs of damage on leaves })\end{array}$ & $\begin{array}{c}\text { Nilai } \\
\text { (Srore) }\end{array}$ \\
\hline Sehat & Tidak ada serangan/daun sehat & 0 \\
Ringan & Luas daun terserang $\leq 10 \%$ & 1 \\
Agak berat & Luas daun terserang $\geq 11-25 \%$ & 2 \\
Berat & Luas daun terserang $\geq 26-45 \%$ & 3 \\
Sangat berat & Luas daun terserang $\geq 46-75 \%$ & 4 \\
Gagal & Luas daun terserang $\geq 76 \%$ & 5 \\
& Daun kering, gundul dan tanaman mati & \\
\hline
\end{tabular}

Sumber (Source): Sugiharso \& Suseno (1983) 


\section{Sebaran}

Kegiatan ini dilakukan untuk mengetahui lokasi sebaran penyakit bercak daun pada tanaman tembesu di Sumatera Bagian Selatan. Kegiatan dilakukan dengan mengamati secara langsung keberadaan penyakit tersebut pada tanaman tembesu. GPS (Global Positioning System) digunakan sebagai alat bantu pencatatan data lokasi untuk mengetahui posisi tanaman tembesu yang terserang penyakit.

\section{Analisa Data}

Analisa data dilakukan menggunakan analisis statistik terhadap parameter yang digunakan nilai rataan, menggunakan simpangan baku (S) dengan persamaan Mattjik Sumertajaya (2000) dan indeks kesamaan (IS) untuk mengetahui kesamaan komunitas antara lokasi pengamatan (Odum, 1971). Rumus statistik tersebut sebagai berikut:

\section{Rataan:}

$$
\bar{x}=\frac{\sum_{i=0}^{n} x i}{n}
$$

2. Simpangan baku:

$$
S=\sqrt{\frac{\sum_{i=1}^{n}(x i-\bar{x})^{2}}{n-1}}
$$

Keterangan (Remarks):

$\mathrm{S}=$ Simpangan baku

$\mathrm{x}=$ Nilai rataan

$\mathrm{n}=$ Jumlah plot contoh

$\mathrm{xi}=$ Nilai pada pengamatan ke-i

3. IS $=\frac{2 \mathrm{C}}{\mathrm{A}+\mathrm{B}} \times 100 \%$

Keterangan (Remarks):

IS $=$ Indeks kesamaan

$\mathrm{C}=$ Jumlah species yang ada pada kedua komunitas

$\mathrm{A}=$ Jumlah species yang ada di komunitas A

$\mathrm{B}=$ Jumlah species yang ada di komunitas B

Nilai Indeks kesamaannya menggunakan kriteria Suin (2002):

(1) Kesamaan $\leq 25 \%=$ sangat tidak mirip,

(2) Kesamaan $\geq 26-50 \%=$ tidak mirip,

(3) Kesamaan $\geq 51-75 \%=$ mirip,

(4) Kesamaan $\geq 76 \%=$ sangat mirip.

\section{HASIL DAN PEMBAHASAN}

\section{A. Hasil Pengamatan}

\section{Inventarisasi dan deskripsi penyakit}

Berdasarkan hasil pengamatan di lapangan dan identifikasi di laboratorium, jenis penyakit yang menyerang tembesu adalah:

\section{a. Penyakit bercak kuning}

\section{1). Gejala serangan}

Serangan penyakit bercak kuning pada daun tembesu menunjukkan gejala awal serangan berupa adanya bercak berwarna kuning, pada bagian ujungnya berpendar. Bercak lokal yang berwarna kuning mengalami mati jaringan sehingga pada bekas bercak tersebut berlubang (shot hole). Pada serangan lanjut daun berubah warna menjadi kuning dan cokelat yang akhirnya daun gugur sebelum waktunya (Gambar 1).

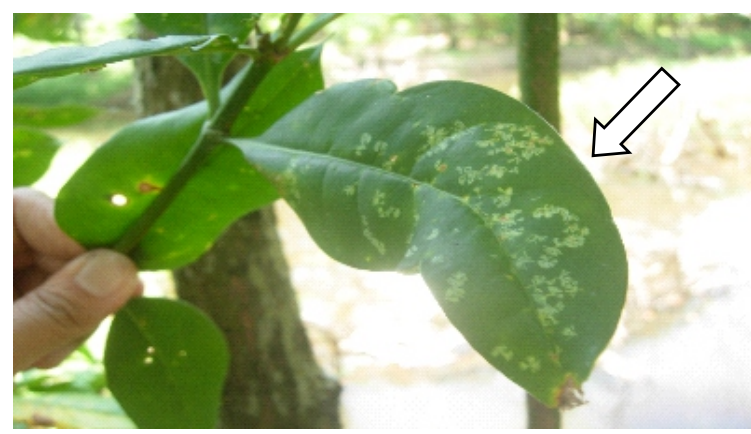

Sumber (Source): Asmaliyah

Gambar(Figure) 1. Gejala bercak daun yang disebabkan oleh cendawan Diplodia mutila (Symptoms of leaf spot caused by the fungus D. mutila)

\section{2) Identifkasi Patogen}

Berdasarkan hasil identifikasi penyebab penyakit bercak daun ini adalah cendawan Diplodia mutila yang masuk dalam famili Sphaeropsidaceae, ordo Sphaeropsidales (Dwidjoseputro, 1978; Alexopoulos, 1979; Barnet \& Hunter (2006). Cendawan membentuk piknidium yang di dalamnya terbentuk piknidiospora/konidium. Piknidiospora berbentuk lonjong atau jorong (elip), berdinding tebal, warna hyalin (transparan) apabila masih muda yang kemudian berubah menjadi coklat tua dengan satu sekat (Gambar 2). 

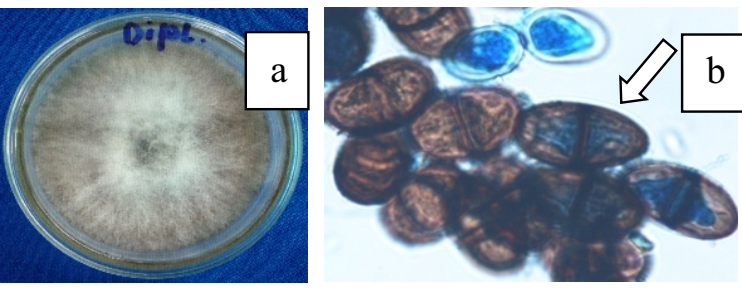

Sumber (Source): Asmaliyah

Gambar(Figure)2. Isolat dari permukaan atas (a) dan konidia (b) tua cendawan D. mutila dengan pembesaran 40x10 (Isolates from upper surface (a) and old conidial (b) fungus D. mutila with magnification 40x10)

\section{b. Penyakit bercak hijau kekuningan}

\section{1) Gejala serangan}

Gejala serangan penyakit ini pada daun tembesu menunjukkan gejala awal serangan berupa adanya bercak bulat kecil, berwarna hijau kekuningan yang terdapat pada bagian bawah permukaan daun. Gejala selanjutnya bercak akan menyatu, semakin melebar dan berubah warna menjadi cokelat kemerahan yang diikuti dengan perubahan warna daun menjadi kuning, selanjutnya daun gugur(Gambar 3).

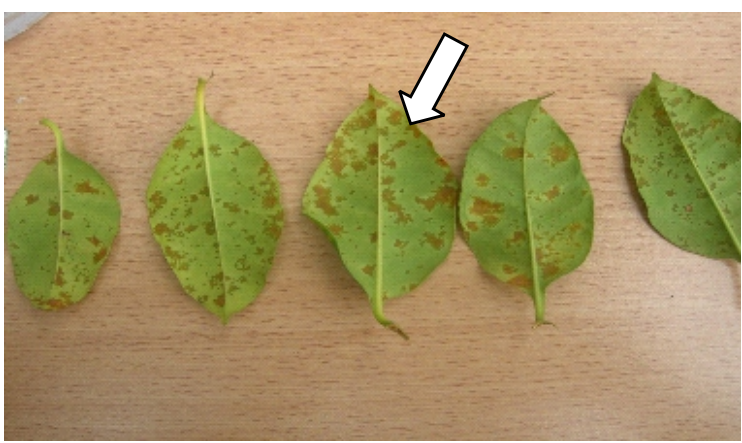

Sumber (Source): Asmaliyah

Gambar(Figure) 3. Gejala bercak daun yang disebabkan oleh cendawan Curvularia sp. (Symptoms of leaf spot caused by the fungus Curvularia sp.)

\section{2) Identifikasi patogen}

Berdasarkan hasil identifikasi patogen bercak daun ini adalah cendawan Curvularia sp., yang termasuk ke dalam kelas Deuteromycetes dan ordo Moniliales (Dwidjoseputro, 1978; Alexopoulos, 1979). Konidiofor dan konidia berwarna cokelat tua dengan sel-sel ujungnya agak jernih. Konidia bersel 3 sampai 5 mempunyai ciri khas melengkung dan sel-sel tengahnya membesar

(Gambar 4). Curvularia sp. adalah cendawan yang dapat terbawa benih, sehingga penyakit bercak daun ini dimulai sejak bibit masih berada di persemaian sampai berbentuk pohon di lapangan.

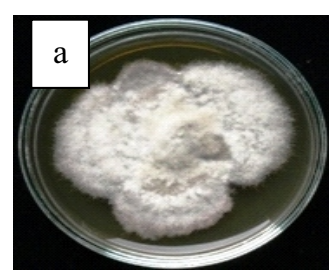

Sumber (Source): Asmaliyah

Gambar(Figure) 4. Isolat dari permukaan atas (a) dan konidia (b) cendawan Curvularia sp. dengan pembesaran 40x10 (Isolates from upper surface (a) and conidia (b) fungus Curvularia sp. with magnification 40x10)

\section{c. Penyakit bercak kuning kecokelatan}

\section{1) Gejala Serangan}

Serangan penyakit bercak cokelat pada daun tembesu menunjukkan gejala awal berupa adanya bercak kuning seperti gejala klorosis. Gejala selanjutnya pada bercak yang berwarna kuning timbul bercak bulat yang berwarna cokelat, yang kemudian akan semakin meluas dengan batas yang tegas. Pada bagian tengah bercak berwarna kelabu/kelabu kehijauan dengan bagian tepinya berwarna coklat agak kemerahan. Kemudian bercak akan mengering, rapuh dan gugur, akibatnya daun akan berlobang. Kadang pada pusat bercak terdapat bintik hitam yang merupakan piknidum (Gambar 5).

\section{2) Identifikasi patogen}

Berdasarkan hasil identifikasi penyebab penyakit bercak daun ini adalah cendawan Pestalotiopsis sp. masuk dalam kelas Deuteromycetes dan famili Melanconiaceae (Dwidjoseputro, 1978; Alexopoulos, 1979). Ciri makroskopisnya adalah koloni berwarna putih, miselium merata, pertumbuhan koloni rata dan tebal. Ciri mikroskopisnya adalah hifa berwarna putih, mempunyai tubuh buah yang disebut aservuli yang terletak di bawah epidermis tanaman inang. Dalam aservuli terdapat konidia yang bersekat 2-5 dengan dinding tebal, konidia berbentuk lonjong agak meruncing pada kedua ujungnya. Pada salah satu ujung konidia terdapat seperti bulu cambuk yang berjumlah 3 atau 5 (Gambar 5). 


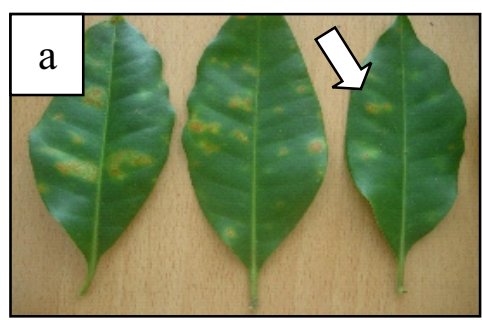

Sumber (Source): Asmaliyah
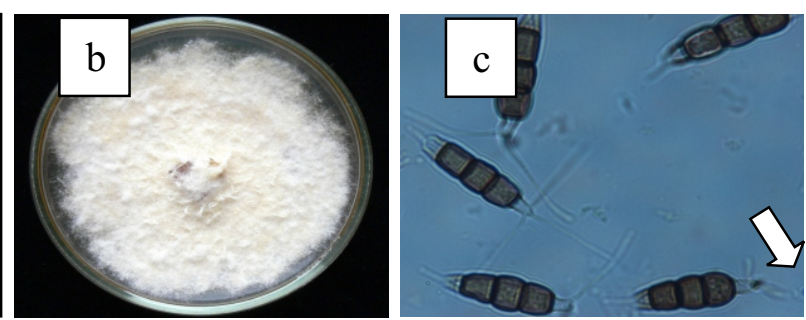

Gambar(Figure) 5. Gejala bercak daun yang disebabkan cendawan Pestalotiopsis sp. (a), isolat dari permukaan atas (b) dan konidia (c) cendawan Pestalotiopsis sp. dengan pembesaran 40x10 (Symptom of leaf spot caused by the fungus Pestalotiopsis $s p$. (a), isolates from upper surface (b) and conidial (c) the fungus Pestalotiopsis sp. with magnification $40 \mathrm{x} 10)$

\section{d. Penyakit bercak coklat}

\section{1) Gejala serangan}

Serangan penyakit bercak cokelat pada daun tembesu menunjukkan adanya bercak bulat, berukuran kecil berwarna cokelat. Selanjutnya bercak akan semakin melebar dan meluas dan membentuk batas yang tegas. Pada bercak yang sudah melebar dan meluas pada bagian tengah bercak berwarna agak lebih lebih terang dibandingkan dengan bercak di sekelilingnya atau tepi. Pada bercak ini kadang-kadang terdapat bintik-bintik hitam yang merupakan piknidium (Gambar 6).

\section{2) Identifikasi patogen}

Berdasarkan hasil identifikasi penyebab penyakit ini adalah cendawan Phyllosticta capitalensis, masuk ke dalam kelas Deuteromycetes, ordo Sphaeropsidales dan famili Sphaeropsidaceae (Alexopoulos, 1979; Dwidjoseputro, 1978). Ciri makroskopisnya koloni berwarna hitam, pertumbuhan koloni rata dan tebal. Ciri mikroskopisnya konidia bersel satu, hialin, mempunyai bentuk jorong atau bulat telur (Gambar 6).

\section{e. Penyakit embun hitam}

\section{1) Gejala serangan}

Serangan penyakit embun hitam pada daun tembesu ditandainya dengan adanya noda-noda atau bercak-bercak berwarna hitam pada permukaan atas daun, seperti jelaga yang kurang merata dan berkelompok. Bercak hitam tersebut kemudian menyatu, menebal dan meluas menutupi seluruh permukaan daun. Bercak hitam tersebut merupakan kumpulan miselium yang menutupi permukaan daun (Semangun, 2007) (Gambar 7). Pada tingkat serangan berat daun akan menjadi kuning dan gugur sebelum waktunya.

\section{2) Identifikasi patogen}

Berdasarkan hasil identifikasi secara makroskopis dan mikroskopis penyebab penyakit embun hitam ini adalah cendawan Meliola sp.. Meliola sp. termasuk kelas Ascomycetes, ordo Meliolales, famili Meliolaceae (Old et al., 2000). Fungi ini bersifat parasit obligat artinya tidak dapat diisolasi dan ditumbuhkan pada media buatan, hanya dapat hidup pada bagian tanaman yang

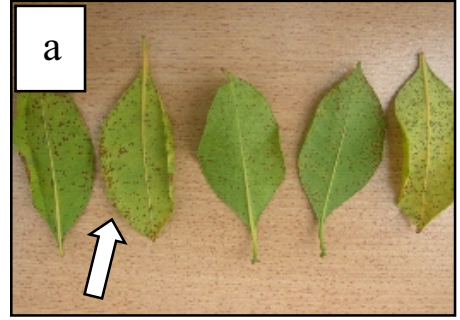

Sumber (Source): Asmaliyah
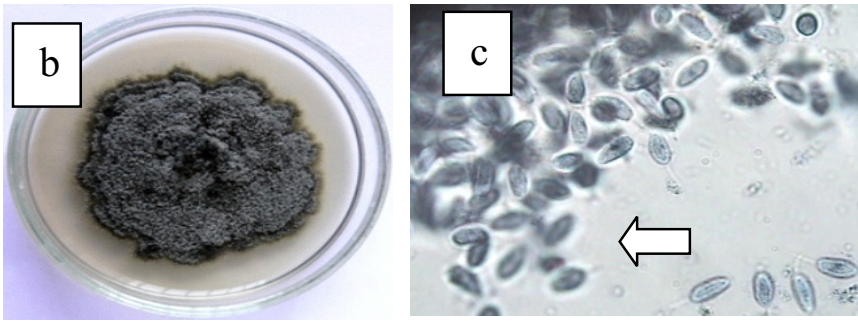

Gambar(Figure)6. Gejala karat daun yang disebabkan oleh cendawan P. capitalensis (a), isolat dari permukaan atas (b) dan konidia (c) cendawan P. capitalensis dengan pembesaran 40x10 (Symptoms of leaf rust caused by the fungus P. capitalensis (a), isolates from upper surface (b) and conidial (c) the fungus P. capitalensis with magnification 40x10) 
masih hidup dan mengganggu jaringan tumbuhan inang dengan jalan mempenetrasi sel inang. Meliola sp. mempunyai hifa yang disebut dengan hipopodia (hifa yang mempunyai tonjolantonjolan di kedua sisi dan berfungsi sebagai alat untuk merekat dan absorpsi pada daun). Askokarp/askus (tubuh buah) disebut pula peritesium karena berbentuk agak bulat yang pada ujungnya terdapat ostiol (lubang untuk keluarnya spora). Spora yang dibentuk dalam askokarp disebut askospora yang berbentuk lonjong memmpunyai warna cokelat agak kehitaman, spora berseptat (Ismail \& Anggraeni, 2008) (Gambar 7).

\section{Sebaran Penyakit}

Lokasi dan posisi sebaran kelima penyakit yang ditemukan pada tanaman tembesu di Sumatera Bagian Selatan disajikan pada Lampiran 1.

\section{Persentase Serangan dan Intensitas Sera- ngan}

Rata-rata persentase serangan dan intensitas serangan masing-masing penyakit dari seluruh lokasi areal tanaman tembesu yang terserang penyakit di wilayah Sumatera Bagian Selatan dapat dilihat pada Tabel 3 .

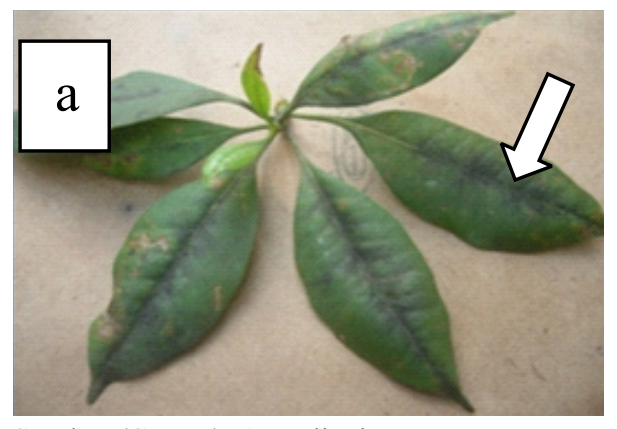

Sumber (Source): Asmaliyah

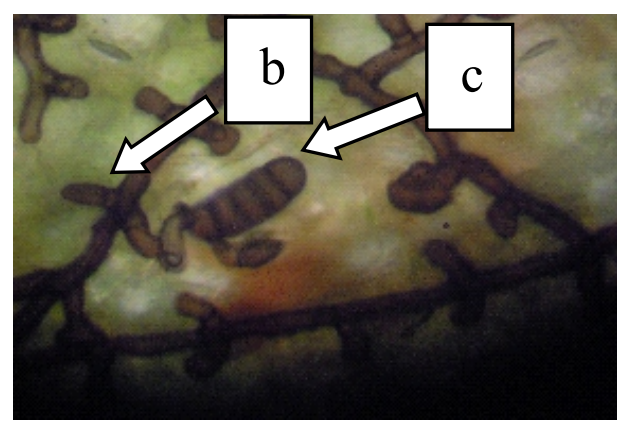

Gambar(Figure) 7. Gejala embun hitam pada daun tanaman tembesu (a), hipopodia (b) dan konidia (c) cendawan Meliola sp. dengan pembesaran 40x10 (Symptom of black mildew on tembesu leaves (a), hipopodia (b) and conidial (c) the fungus Meliola sp. with magnification 40x10)

Tabel(Table)3. Rata-rata persentase serangan dan intensitas serangan penyakit daun pada tanaman tembesu (Means of attack percentage and attack intensity leaf diseases on tembesu plantation)

\begin{tabular}{|c|c|c|c|c|c|c|}
\hline \multirow[t]{2}{*}{ No. } & \multirow[t]{2}{*}{$\begin{array}{c}\text { Jenis penyakit/patogen } \\
\text { (Diseases/pathogen })\end{array}$} & \multicolumn{2}{|c|}{$\begin{array}{c}\text { Persentase serangan } \\
\text { (Percentage of } \\
\text { attacking) }(\%)\end{array}$} & \multicolumn{2}{|c|}{$\begin{array}{c}\text { Intensitas serangan } \\
\text { (Intensity of attacking) } \\
(\%)\end{array}$} & \multirow[t]{2}{*}{$\begin{array}{l}\text { Kategori } \\
\text { (Category) }\end{array}$} \\
\hline & & Rata $^{2}$ & $\mathrm{~S}$ & Rata $^{2}$ & $S$ & \\
\hline 1. & Diplodia mutila & 90,30 & 2,10 & 20,36 & 3,21 & agak berat \\
\hline 2. & Curvularia sp. & 45,00 & 17,56 & 16,67 & 6,67 & agak berat \\
\hline 3. & Pestalotiopsis sp. & 25,44 & 6,12 & 11,45 & 2,71 & agak berat \\
\hline 4. & Phyllosticta capitalensis & 36,43 & 5,20 & 17,40 & 3,07 & agak berat \\
\hline 5. & Meliola $\mathrm{sp}$. & 80,00 & 10,00 & 22,98 & 2,40 & agak berat \\
\hline
\end{tabular}

Sumber (Source): Diolah dari data lapang (Compiled and analyzed from field data)

Keterangan (Remarks): S = Simpangan baku (Standard deviation) 


\section{B. Pembahasan}

Berdasarkan hasil pengamatan menunjukkan bahwa penyakit bercak daun yang disebabkan oleh cendawan $D$. mutila paling luas sebarannya. Serangan penyakit tersebut tidak saja tersebar pada sebagian besar tanaman tembesu di wilayah Propinsi Sumatera Selatan, tetapi tersebar juga di wilayah Propinsi Lampung dan Jambi. Luasnya sebaran patogen Diplodia diduga karena patogen ini mempunyai daerah sebaran yang luas dan penyebarannya cepat dari satu tempat ketempat yang lain, seperti yang dikemukakan oleh Iturritxa et al., (2013). Pada fase istirahat di dalam inang patogen ini dapat dilepaskan karena stres air dan kekeringan parah. Serangan patogen Diplodia ini ditemukan mulai dari daerah dataran rendah sampai di pegunungan dan di beberapa tempat menyebabkan penyakit yang cukup serius pada berbagai jenis tanaman. Di Jawa penyakit Diplodia ini mempunyai arti penting di daerah dataran rendah pada tanaman jeruk keprok dan jeruk besar (Semangun, 2007). Di luar negeri, di Iran, genus Diplodia merupakan ancaman yang serius bagi tanaman Zelkova carpinifolia di hutan pegunungan Alborz (Mirabolfathy, 2013) dan pohon apel di kebun Azerbaijan barat (Hanifeh et al., 2013). Serangan patogen genus Diplodia ini ditemukan di banyak negara di dunia, di antaranya Amerika Serikat, Mexico, Eropa Bagian Selatan dan Utara, Australia, Afrika Selatan dan Iran yang menyebabkan penyakit bercak atau hawar daun/pucuk, kanker batang/cabang pada beberapa tanaman hutan dan herba (Phillips et al., 2007; Oblinger et al., 2011 dan Mirabolfathy, 2013. Oleh karena itu, keberadaan penyakit tersebut perlu dikendalikan mengingat tingkat kerusakan tanaman akibat serangannya pada tanaman tembesu sudah mencapai kategori serangan agak berat.

Intensitas serangan atau tingkat kerusakan tanaman akibat serangan $D$. mutila tertinggi terjadi di Desa Talang Lumut, Kecamatan Medang Suku I-OKUT dan Desa Kampung Harapan, Kecamatan Banyuasin III-Banyuasin, dengan intensitas serangan sebesar 45\%, sedangkan terendah terjadi di Desa Simpang Karta Mulya, Kecamatan Medang, Suku I-OKUT, dan Desa Mekar Sari, Kecamatan Pelawan Singkut-Sarolangun, Jambi, dengan intensitas serangan sebesar 5\%. Diduga jarak tanam yang sangat rapat antar tanaman ( 1 x $1 \mathrm{~m}$ dan $1 \times 2 \mathrm{~m}$ ) dan tajuk saling tumpang tindih serta tidak adanya pemeliharaan terhadap tumbuhan bawah dan tanaman menyebabkan kondisi lingkungan, terutama iklim mikro di sekitar tanaman di Desa Talang Lumut dan di Desa Kampung Harapan sangat mendukung untuk perkembangan penyakit. Terjadinya interaksi dan kecepatan proses interaksi antara patogen dan inang sangat ditentukan oleh iklim mikro (Widyastuti et al., 2005). Hasil pengamatan di lapangan menunjukkan bahwa tanaman tembesu di dua lokasi tersebut tidak saja terserang penyakit yang disebabkan oleh cendawan D. mutila, tetapi juga terserang penyakit daun lainnya yang disebabkan oleh Curvularia sp. di Desa Kampung Harapan dan $P$. capitalensis di desa Talang Lumut. Diduga juga akibat kondisi tanaman yang rapat dan tidak adanya pemeliharaan terhadap tumbuhan bawah dan tegakan di Desa Jati Sari, Kecamatan Madang Suku I-OKUT, dan di Desa Muara Bulian, Kecamatan Muara Bulian-Batang Hari, Jambi yang menyebabkan kondisi areal tersebut sangat rentan terhadap serangan berbagai penyakit.

Berbeda dengan dua desa lainnya, yaitu Desa Simpang Karta Mulya dan Mekar Sari, jarak tanam antar tanaman tembesu dan tanaman agroforestri lainnya lebih lebar $(5 \times 5 \mathrm{~m})$ dan pemeliharaan terhadap tumbuhan bawah dan tegakan cukup intensif dilakukan, sehingga kondisi lingkungan tidak mendukung untuk perkembangan penyakit. Jarak tanam yang lebar dan penyiangan terhadap gulma dan rumput-rumputan serta pemangkasan tajuk dapat mengurangi kelembaban dan sirkulasi udara cukup lancar serta tanaman semakin sehat (Widyastuti et al., 2005).

Sementara tiga penyakit lainnya yang disebabkan oleh cendawan Pestalotiopsis sp., $P$. capitalensis dan Curvularia sp. juga sudah tersebar di Sumatera Bagian Selatan, tetapi terbatas hanya di beberapa lokasi saja (Lampiran 1). Namun tingkat kerusakan tanaman akibat serangan tiga patogen tersebut sudah termasuk kategori serangan agak berat (Tabel 3), sehingga keberadaan penyakit ini harus diwaspadai. Menurut Anggraeni (2011), kerusakan akibat serangan cendawan Pestalotia (Pestalotiopsis) sp. pada tanaman meranti dapat menghambat pertumbuhan tanaman, bahkan pada serangan berat dapat menyebabkan kematian tanaman Skubung (Maccarangagigantea).

Begitu juga penyakit embun hitam yang disebabkan oleh cendawan Meliola sp. hanya ditemukan di desa Sidomulyo, Kecamatan Tungkal Ilir, Kabupaten Banyuasin, namun tingkat kerusakan tanaman akibat serangan penyakit tersebut sudah termasuk kategori serangan agak berat (Tabel 3). Menurut Widyastuti et al., 2005) jika serangan penyakit embun jelaga cukup berat, 
proses fotosintesis tanaman dapat terganggu sehingga pertumbuhan terhambat. Artinya tindakan pengendalian sudah harus dilakukan, agar kerugian akibat serangan penyakit dapat diminimalkan. Walaupun tidak sampai mematikan tanaman, kerusakan akibat serangan penyakit embun hitam pada tanaman Acacia spp. dapat mempengaruhi pertumbuhan tanaman karena bercak hitam di permukaan daun dapat mengganggu proses fotosintesis, akibatnya daun menjadi kuning dan gugur (Hidayati, 2013). Tingginya tingkat kerusakan tanaman akibat serangan penyakit embun hitam, diduga kuat disebabkan karena posisi tanaman tembesu sebagai tanaman pagar yang terletak di pinggir jalan utama. Kondisi ini membuat tanaman tembesu tercekam akibat adanya partikel debu dan/atau polutan udara lainnya (diantaranya dari kendaraan bermotor) yang melekat pada daun tembesu, sehingga metabolisme tanaman menjadi terganggu. Cekaman terhadap tanaman tembesu ini semakin meningkat dengan meningkatnya intensitas cahaya yang sering terjadi pada tanaman tembesu tersebut karena terletak di bagian yang paling terbuka. Faktor-faktor ini menyebabkan tanaman menjadi lemah atau rentan, sehingga membuka peluang lebih besar terhadap infeksi patogen parasitik (Widyastuti et al., 2005).

Tindakan pengendalian (pengelolaan) yang dapat dilakukan untuk mengurangi serangan penyakit Diplodia atau penyakit bercak daun lainnya dan embun jelaga adalah: (1) sanitasi dan eradikasi dengan membersihkan gulma dan membakar daun-daun, tangkai atau cabang yang gugur untuk menciptakan kondisi yang cocok bagi tanaman dan menekan jumlah inokulum (Oblinger et al., 2011; Triwibowo et al., 2014); (2) pengaturan jarak tanam jangan terlalu rapat dan kegiatan pemangkasan pada tanaman yang dewasa efektif mengurangi kelembaban; (3) penerapan pola tanam agroforestri, selain dapat melindungi hutan dari serangan penyakit, juga dapat meningkatkan vigoritas tanaman yang sehat (Widyastuti et al., 2005); (4) menggunakan agens antagonis bakteri Bacillus sp. dan $B$. subtilis (Handoko et al., 2014), campuran ekstrak alami teh dengan mikroba antagonis Candida ernobii (Liu et al., 2010); (5) menggunakan ekstrak bawang putih, vanili dan chitosan oligosaccharida (Rebeca et al., 2015); (6) menggunakan air deterjen atau larutan pencuci piring dengan dosis $1 \mathrm{ml}$ cairan pembersih ditambah 99 $\mathrm{ml}$ air untuk pengendalian penyakit embun jelaga (Pole \& Wasilwa, 2014); dan 7) jika diperlukan dapat menggunakan fungisida benzimidazole (Gonzalo et al., 2013).
Berdasarkan hasil uji kesamaan komunitas, terlihat bahwa di Desa Jati Sari cenderung tidak mirip (nilai indeks kesamaannya berkisar antara 40\%-50\%) dengan sebagian besar lokasi lainnya dan sangat tidak mirip (nilai indeks kesamaannya 0) dengan Desa Kangkung, Desa Mengulak dan Desa Sidomulya. Begitu juga dengan Desa Muara Bulian cenderung tidak mirip (nilai indeks kesamaannya berkisar antara 40-50\%) dengan sebagian besar lokasi lainnya dan sangat tidak mirip (nilai indeks kesamaannya 0) dengan Desa Kangkung dan Desa Sidomulyo. Begitu juga dengan Desa Kangkung, Desa Mengulak dan Desa Sidomulya sangat tidak mirip (nilai indeks kesamaannya 0) dengan lokasi lainnya. Namun demikian sebagian besar lokasi lainnya mempunyai komunitas penyakit yang dapat dikatakan mirip (nilai indeks kesamaannya 67\%) dan sangat mirip (nilai indeks kesamaannya berkisar antara 80-100\%). Kondisi yang tidak mirip ini diduga karena perbedaan dalam pola tanam. Desa Sidomulya, Desa Mengulak dan Desa Jati Sari menerapkan pola tanam campuran dan agroforestri dengan jumlah tanaman hanya 2 jenis, yaitu menanam tanaman tembesu dengan jati (Desa Sidomulya) dan tembesu dengan karet (Desa Mengulak dan Jati Sari), sedangkan di Desa Kangkung menerapkan pola tanam mono-kultur dan di Desa Muara Bulian menerapkan pola tanam campuran dengan berbagai jenis tanaman kehutanan (diantaranya bengkal (Milletia sp.), Kelat (Mischocarpus sp.), dan Simpur (Dillenia sp.). Lokasi lainnya yang cenderung mirip dan sangat mirip menerapkan pola tanam secara agroforestri dengan mencampur tanaman tembesu dengan tanaman kehutanan (antara lain Jati (Tectona grandis), Mahoni (Swietenia macrophylla), dan Jelutung (Dyera sp.) dan tanaman pertanian/ perkebunan (antara lain Pisang (Musa sp.), karet (Hevea brasiliensis) dan kopi (Coffea sp.). Nair (1993) dan Mindawati (2012), menyatakan bahwa pola tanam agroforestri dan campuran dengan pemilihan jenis tanaman yang tepat lebih tahan terhadap serangan hama dan penyakit.

\section{KESIMPULAN DAN SARAN}

\section{A. Kesimpulan}

Penyakit yang ditemukan pada tegakan tembesu, baik tegakan alami maupun tegakan hasil penanaman di Sumatera Bagian Selatan adalah penyakit daun yang disebabkan oleh cendawan D. mutila, Curvularia sp., Pestalotiopsis sp., P. capitalensis dan Meliola sp. Intensitas serangan 
atau tingkat kerusakan tanaman akibat serangan penyakit-penyakit tersebut termasuk kategori serangan agak berat. Penyakit yang paling luas sebarannya adalah penyakit daun yang disebabkan oleh cendawan $D$. mutila dengan intensitas serangan atau tingkat kerusakan tanaman sebesar $20,36 \%$ dengan simpangan baku 3,21\%. Penyakit yang paling terbatas keberadaannya adalah penyakit embun jelaga yang disebabkan cendawan Meliola sp., namun tingkat kerusakan tanaman paling tinggi yaitu sebesar 22,98\% dengan simpangan baku 2,40\%. Kemiripan/kesamaan komunitas penyakit antara lokasi pengamatan dipengaruhi oleh pola tanam.

\section{B. Saran}

Dalam membangun hutan tanaman tembesu agar meminimalisir dampak serangan penyakit daun adalah jarak tanam tidak boleh terlalu rapat dan pola tanamnya perlu dilakukan secara agroforestri. Jarak tanam awal 5 x $5 \mathrm{~m}$ mampu mengendalikan serangan penyakit daun.

\section{UCAPAN TERIMA KASIH}

Ucapan terima kasih disampaikan kepada Andika Imanullah dan Nesti Andriani yang telah banyak membantu dalam pelaksanaan penelitian dan pengumpulan data.

\section{DAFTAR PUSTAKA}

Alexopoulos, C.J., \& Mims, C.W. (1979). Introduction Mycology. John Wiley \& Sons.

Anggraeni, I., \& Wibowo, A. (2007). Pengaruh pola tanam wanatani terhadap timbulnya penyakit dan produktivitas tanaman tumpang sari. Info Hutan Tanaman, 2(2).

Anggraeni, I., \& Mindawati, N. (2011). Serangan hama dan penyakit pada gmelina (Gmelina arborea Roxb.) di Hutan Rakyat. Tekno Hutan Tanaman, 2(2).

Anggraeni, I., \& Lelana, N.E. (2011). Diagnosis penyakit tanaman hutan. Badan Penelitian dan Pengembangan Kehutanan, Pusat Penelitian dan Pengembangan Peningkatan Produktivitas hutan.

Anggraeni, I. (2012). Penyakit karat tumor pada sengon dan hama cabuk lilin pada pinus. Akses tanggal 4 Maret 2014, dari http://www.forda. mof.org.
Barnett, H.I., \& Hunter, B. (2006). Illustrated genera of imperfect fungi. Fourth Edistion. St. Paul, Monnesota: APS Press. The American Phytopathological Society.

Direktorat Perlindungan Tanaman. (2000). Pedoman pengamatan dan pelaporan tanaman pangan. Jakarta: Departemen Pertanian.

Dwidjoseputro, D. (1978). Pengantar mikologi. Bandung: Penerbit Alumni.

Gonzalo, A.D., \& Bernardo, A.L. (2013). Efficacy of paste and liquid fungicide formulation to protect pruning wound against pathogens associated with grapevine trunk. Crop Protection, 46.

Guyot, J., Condina, V., Doare, F., Cilas, C., \& Sache, I. (2014). Role of ascospores and conidia in the initiation and spread South American leaf blight in rubber tree plantation. Plant Patho$\log y, 63$.

Handoko, A., Abadi, A.L., \& Aini, L.Q. (2014). Karakterisasi penyakit penting pada pembibitan tanaman durian di Desa Plangkrongan, Kabupaten Magetan dan pengendalian dengan bakteri antagonis secara invitro. Jurnal Hama dan Penyakit Tumbuhan Tropika, 2(2).

Hanifeh, S., Ghoosta, Y., Abbasi, S., Phillips, A.J.L. (2013). First report of Diplodia malorum Fuckel the causal agen of canker disease of Apple trees in Iran. Iranian Journal of Plant Pathology, 49(2).

Hidayati, N. (2013). Penyakit-penyakit penting pada tanaman hutan rakyat dan alternatif pengendaliannya. Balai Besar Pemuliaan Bioteknologi dan Pemuliaan Tanaman Hutan. Akses tanggal 15 Oktober 2015, dari: http://www. forda-mof.org.

Ismail, B., \& Anggraeni, I. (2008). Identifikasi penyakit jati (Tectona grandis) dan akasia (Acacia auriculiformis) di hutan rakyat Kabupaten Wonogiri, Jawa Tengah. Jurnal Pemuliaan Tanaman Hutan, 2(1).

Iturritxa, E., R.J. Ganley, R. Raposo, I.G. Serna, N. Mesanza, S.C. Kirkpatrick and T.R. Gordon. (2013). Resistance levels of spanish conifers against Fusarium circinatum dan Diplodia pinea. Forest Pathology, 43.

Liu, H.M., Guo, J.H., Liu, P., Cheng, Y.J., Wang, B.Q., Long, C.A., \& Deng, B.X. (2010). Inhibitory activity of tes polyphenol and Candida ernobii against Diplodia natalensis infection. Journal of Applied Microbiology, 108, Issue 3.

Mattjik, A.A., \& Sumertajaya, M. (2000). Perancangan Percobaan dengan Aplikasi SAS dan Minitab. Jilid I. IPB Press. 
Mindawati, N. (2012). Tinjauan tentang pola tanam hutan rakyat. Tanggal akses 21 Mei 2012 dari: http://dishut.jabarprov.go.id.

Mirabolfathy, M. (2013). First report of Diplodia seriata from Zelkova carpinifolia with canker symptoms in iran. Iran. J. Plant Path., 49, (1).

Nair, P.K.R. (1993). An Introduction to Agroforestry. Nairobi: Kluwer Academic Publ.

Nurhayati, Fatma, \& Aminuddin, M.I. (2010). Ketahanan enam klon karet terhadap infeksi Corynespora cassicola penyebab penyakit gugur daun. Jurnal Hama dan Penyakit Tumbuhan Tropika, 10(1).

Oblinger, B.W., Smith, D.R., \& Stanosz, G.R. (2011). Red pine harvest debris as a potential source of inoculum of Diplodia shoot bligt pathogens. Forest Ecology dan Management, 262 (Issue 4).

Odum, E.P. (1971). Fundamentals of ecology, 3rd Ed. Saunders, Philadelphia.

Old, K.M., See, L.S., Sharma, J.K., \& Yuan, Z.Q. (2000). A Manual of Diseases of Tropical Acacias in Australia, South East Asia and India. Jakarta: Center for International Forestry Research (CIFOR).

Phillips, A.J.L., Crous, P.A., \& Alves, A. (2007). Diplodia seriata, the anamorph of "Botryosphaeria” obtusa. Fungal Diversity 25.

Pole, F., \& Wasilwa, L. (2014). Mango sooty mold (Meliola mangiferae). KARI/Mimea Factsheet No.17.2014. Akses tanggal 15 Oktober 2015, dari: http://www.kari.org.

Rahayu, S. (2008). Penyakit karat tumor pada sengon (Falcataria moluccana (Miq) Barneby \& J.W. Grimes). Makalah Workshop Penanggulangan Serangan Karat Puru pada Tanaman Sengon. Yogyakarta 10 Nopember 2008. Balai Besar Penelitian Bioteknologi dan Pemuliaan Tanaman Hutan. Akses 4 Maret 2014 dari: http://www.biotifor.or.id.
Rahayu, S., See, L.S., \& Shukor, N.A. (2010). Uromycladium tepperianum, the gall rust fungus from Falcataria moluccana in Malaysia and Indonesia. Mycoscience, 51, 149-153.

Rebeca, C., M.R. Maria, A.P.J. Manuel, O.M. Angel, S. Silvia, G.G. Sandra, G.J. Enrique and R.C.J. Jose. (2015). Effectiviness of natural antifungal compounds in controlling infection by grapevine trunk diseases pathogens through pruning wounds. Applied dan Environmental Microbiology, 81 (Issue 18).

Semangun, H. (2007). Penyakit-penyakit tanaman hortikultura di Indonesia (Revisi). Yogyakarta: Gadjah Mada University Press.

Sugiharso, \& Suseno. (1983). Diktat dasar-dasar perlindungan tanaman. Bagian Ilmu Penyakit Tumbuhan. Bogor: Fakultas Pertanian Institut Pertanian Bogor.

Siun, N.M. (2002). Metode ekologi. Padang: Universitas Andalas.

Triwibowo, H., Jumani, \& H. Emawati. (2014). Identifikasi hama dan penyakit Shorea leprosula Miq. Di Taman Nasinal Kutai Resort Sangkima Kabupaten Kutai Timur Provinsi Kalimantan Timur. Jurnal Agrifor, XIII(2).

Triyogo, A dan S.M. Widyastuti. 2011. Peran serangga sebagai vektor penyakit karat puru pada sengon (Albizia falcataria L. Fosberg). Jurnal Agron Indonesia, 40 (I).

Umrah, T., Anggraeni, R.R., Esyanti, \& Aryantha, I.N.P. (2009). Antagonisitas dan efektivitas Trichoderma sp. dalam menekan perkembangan Phytopthora palmivora pada buah kakao. J. Agroland, 16.

Widyastuti, S.M., Sumardi, \& Harjono. (2005). Patologi Hutan. Yogyakarta: Gadjah Mada University Press. 


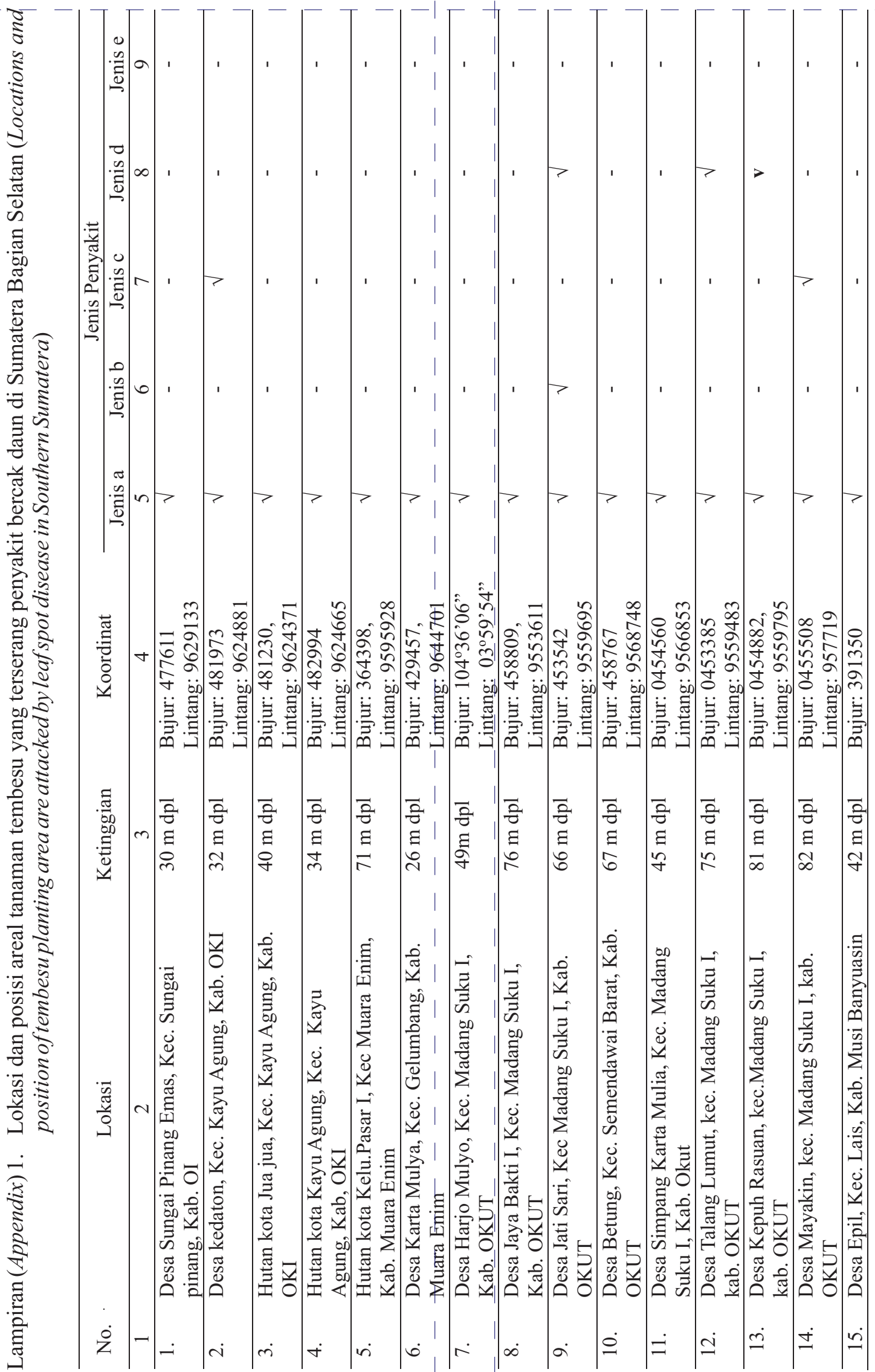




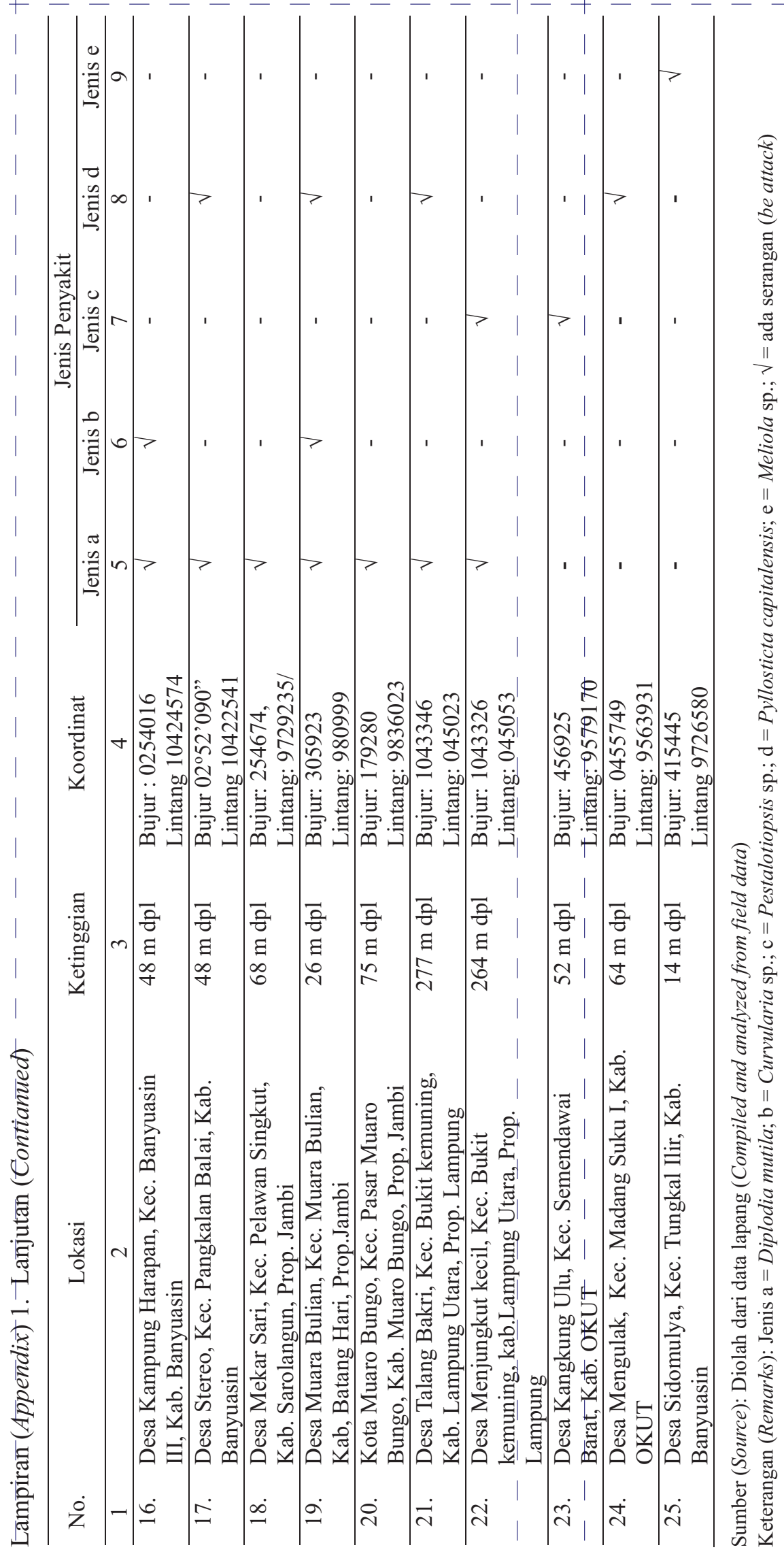

